Original Article

\title{
Length-weight relationship: eight species of Cyprinidae from river Panjkora, Khyber Pakhtunkhwa, Pakistan
}

\author{
Relação peso-comprimento: oito espécies de Cyprinidae do rio Panjkora, Khyber \\ Pakhtunkhwa, Paquistão
}

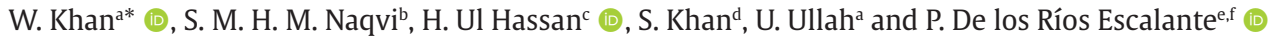 \\ aUniversity of Malakand, Department of Zoology, Laboratory of Parasitology, Lower Dir, Pakistan \\ ${ }^{b}$ Pakistan Agricultural Research Council - PARC, Southern Zone Agricultural Research Center - SARC, Outreach Research Activity \\ Unit - ORAU, Karachi, Pakistan \\ cUniversity of Karachi, Department of Zoology, Karachi, Pakistan

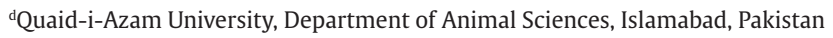 \\ eUniversidad Católica de Temuco, Facultad de Recursos Naturales, Departamento de Ciencias Biológicas y Químicas, Temuco, Chile \\ fNúcleo de Estudios Ambientales UC Temuco, Casilla, Temuco, Chile
}

\begin{abstract}
Seven hundred and twenty four fish specimens were captured from March to September 2016. The materials used in the current study were cast nets, hand nets. Eight cyprinid fish species were studied for their lengthweight relationships. Parameter b in the LWR was 3.03, 3.06, 3.02, 2.29, 2.82, 3.43, 2.73 and 2.47 for Schizothorax plagiostomus, Schizothorax esocinus, Racoma labiata, Tor putitora, Barilius vagra, Garra gotyla, Puntius ticto and Arassius auratus respectively. Current study is the first attempt on the LWRs of cyprinid species, provide a baseline approach for conservation and /management of local fish fauna of economic importance.
\end{abstract}

Keywords: length weight relationship, cyprinids, snow trout, fresh water fishes, river Panjkora.

\begin{abstract}
Resumo
Um total de 724 espécimes de peixes foi capturado de março a setembro de 2016. Os materiais usados no presente estudo foram redes de lançamento, redes de mão. Oito espécies de peixes ciprinídeos foram estudadas quanto às suas relações peso/comprimento. $O$ parâmetro $b$ no LWR foi 3,03, 3,06, 3,02, 2,29, 2,82, 3,43, 2,73 e 2,47 para Schizothorax plagiostomus, Schizothorax esocinus, Racoma labiata, Tor putitora, Barilius vagra, Garra gotyla, Puntius ticto e Arassius auratus respectivamente. O estudo atual é a primeira tentativa sobre os LWRs de espécies de ciprinídeos, fornecendo uma abordagem de base para a conservação e o manejo da ictiofauna local de importância econômica.
\end{abstract}

Palavras-chave: relação peso/comprimento, ciprinídeos, truta das neves, peixes de água doce, rio Panjkora.

\section{Introduction}

Research on relationship between length (L) and weight (W) of fish species is an approach towards management of fisheries as it provides required data for stocking the fishes (Bagenal and Tesch, 1977). Current study is important for researchers and managers of fisheries in two important determinations as (1) to guess the $\mathrm{W}$ from the $\mathrm{L}$ of a fish and (2) to match the average related factors between groups of fishes. The association between $\mathrm{L}$ and $\mathrm{W}$ of a given fish species can be used for suggesting that a weightier fish of a given $\mathrm{L}$ is in a healthier condition.

River Panjkora Lower Dir is famous for its ichthyofaunal diversity among the fresh water reservoirs of the country. Recently these fish have been studied by Ahmad et al.
(2020), Khalid et al. (2021), Khan et al. (2021). In the present investigation, 724 specimens belonging to eight species of a family cyprinidae from the subjected area were studied to learn their length-weight relationships.

\section{Materials and Methods}

Lower Dir district is located at $34^{\circ}, 37^{\prime}$ to $35^{\circ}, 07^{\prime}$ North and $71^{\circ}, 31^{\prime}$ to $72^{\circ}, 14^{\prime}$ East in Pakistan and lies 823 meters asl. River Panjkora is originated in Dir (Upper) in vicinity of Kohistan. It flows toward south and passes over the mid of entire Dir districts. River Panjkora meets with river Swat

*e-mail: walikhan.pk@gmail.com

Received: August 29, 2020 - Accepted: February 17, 2021 
at Totakan in Malakand district near Bosaq Bridge. Fishes were collected from River Panjkora, Khyber Pakhtunkhwa Pakistan. The fish samplings were made by cast net and hand net from March to September 2016. Each of the fish specimens were identified by using the keys "Inland fishes of India and adjacent countries provided by Talwar and Jhingran (1991), freshwater fishes of the Indian region (Jayaram, 2006), Fishes of the Punjab (Mirza and Sandhu, 2007) and an Urdu key by Mirza (1990) namely “Pakistanki Taza Pani ki Machliyan". Sample of fishes were measured for standard $\mathrm{L}$ to the nearest $0.1 \mathrm{~cm}$ and total weight (TW) to the nearest $0.1 \mathrm{~g}$. This association between $L$ and $W$ were commonly expressed by the equation, $W=\mathrm{a} \times L \mathrm{~b}$, and usually converted into its logarithmic expression, log $W=\log \mathrm{a}+\mathrm{b} \times \log L$, where $W$ is body weight $(\mathrm{g})$, and $L$ is the total length, standard length, or fork length $(\mathrm{cm})$. The $95 \%$ confidence level for b was measured to calculate if the hypothetical value of isometry fell within these limits (Froese, 2006). Of 5\% significant level (a) was adopted in all the cases. The Excel Microsoft Office 2010 was used for analysis.

\section{Results}

Eight cyprinidian fish species were studied for the relationship between body length and body weight, collected from river Panjkora, Pakistan. Descriptive statistics and estimated parameters, including sample sizes $(n)$, range of body length and weight, $\mathrm{a}$ and $\mathrm{b}$ factors and their confidence level as 95\%, as well as coefficients of determinations $(r 2)$, are presented in Table 1 . The LWR b values for three species includes S. esocinus, S. plagiostomus, and $R$. labiata near to 3.0 which represented the ideal shape of fish with isometric growth. T. putitora, B. vagra, P. ticto and C. auratus, were estimated $b>3.0$, which showed allometric growth, however G.gotyla was recorded $b<3.0$ that showed negative allometric growth.

\section{Discussion}

River Panjkora and river Swat are the main freshwater ecosystem in Malakand region, Pakistan. These rivers have been focused for fish diversities by various scholar in the region. In current study maximum number of fish species collected from river Panjkora followed to the typical b values of 2.5 to 3.5 even this factor is different significantly within the limit (Froese, 2006). Greater b values of regression slope presented that the LWRs of a specific species followed the cube law. Great b values are a consideration for the general condition of appetite and gonad content of the fish (Pervin and Mortuza, 2008). When the fish utilizes the food items available in the surroundings lead to increase the weight of fish (Kamaruddin et al., 2011; Offem et al., 2007). Froese, (2006) stated that valid b values may range from 2.5 to 3.5 ; thus, our parameters (2.292-3.435) can be used safely within the indicated length range.

The present study findings are the first attempt and a required step to the current literature regarding the association between $\mathrm{L}$ and $\mathrm{W}$ of the fish. The findings of the current research will be useful for assessment and conservation of the explored species.

Table 1. Descriptive analysis and fitted LWRs for eight cyprinid species river Panjkora, Pakistan.

\begin{tabular}{|c|c|c|c|c|c|c|c|c|}
\hline Species & $\mathbf{N}$ & $\begin{array}{c}\text { SL range } \\
(\mathrm{cm}) \\
\text { Min-Max }\end{array}$ & $\begin{array}{c}\text { TW } \\
\text { range } \\
\text { (g) } \\
\text { Min-Max }\end{array}$ & $a$ & $\boldsymbol{b}$ & $r 2$ & a CL 95\% & b CL 95\% \\
\hline $\begin{array}{c}\text { S.plagiostomus } \\
\text { Heckel, } 1838\end{array}$ & 200 & $10.2-46$ & $160-865$ & 0.593 & 3.032 & 0.97 & 0.058 to 0.0121 & $2.815-3.251$ \\
\hline $\begin{array}{c}\text { S.esocinus } \\
\text { Heckel) } 1838\end{array}$ & 35 & $10.5-31$ & $200-700$ & 0.024 & 3.068 & 0.98 & -0.062 to -0.091 & $2.832-3.305$ \\
\hline $\begin{array}{c}\text { R.labiatus } \\
\text { McClelland, } 1842\end{array}$ & 168 & $9-35.5$ & $142-675$ & 0.0435 & 3.027 & 0.95 & 0.035 to 0.0521 & $2.920-3.135$ \\
\hline $\begin{array}{c}\text { T.putitora } \\
\text { Hamilton } 1822\end{array}$ & 28 & $8.5-20$ & $130-300$ & 0.0032 & 2.292 & 0.80 & -0.017 to 0.0256 & $2.131-2.451$ \\
\hline $\begin{array}{c}\text { B.vagra } \\
\text { Hamilton } 1822\end{array}$ & 48 & $4.2-9.5$ & $28-130$ & 0.039 & 2.828 & 0.89 & 0.032 to 0.046 & $2.725-2.932$ \\
\hline $\begin{array}{c}\text { G.gotyla } \\
\text { Gray } 1832\end{array}$ & 20 & $7-19$ & $120-300$ & 0.0071 & 3.435 & 0.99 & 0.0179 to 0.0367 & $2.882-3.988$ \\
\hline $\begin{array}{c}\text { P.ticto } \\
\text { Hamilton, } 1822\end{array}$ & 45 & $3-9$ & $25-105$ & 0.0044 & 2.73 & 0.91 & -0.020 to -0.024 & $2.623-2.901$ \\
\hline $\begin{array}{c}\text { C.auratus } \\
\text { Linnaeus, } 1758\end{array}$ & 180 & $8-19$ & $190-450$ & 0.0029 & 2.471 & 0.85 & -0.0314 to 0.0034 & $2.310-2.649$ \\
\hline
\end{tabular}




\section{Acknowledgements}

Higher education commission Pakistan is acknowledged for providing the mini-project \# SRGP 21-61 resulting for providing the required facilities to conduct the study.

\section{References}

AHMAD, A., KHAN, W., DAS, S.N., PAHANWAR, W.A., KHALID, S., MEHMOOD, S.A., AHMED, S., KAMAL, M., AHMED, M.S., HASSAN, H.U. and ZAHOOR, S., 2020. Assessment of ecto and endo parasites of Schizothorax plagiostomus inhabiting river Panjkora, Khyber Pakhtunkhwa, Pakistan. Brazilian Journal of Biology, vol. 81, pp. 92-97.

BAGENAL, T.B. and TESCH, F.W., 1977. Age and growth. In: T.B. BAGENAL, ed. Methods for assessment of fish production in fresh waters. 3rd ed. Oxford: Blackwell Scientific Publications, pp. 101-136.

FROESE, R., 2006. Cube law, condition factor and weight-length relationships: history, meta-analysis and recommendations. Journal of Applied Ichthyology, vol. 22, no. 4, pp. 241-253. http:// dx.doi.org/10.1111/j.1439-0426.2006.00805.x.

JAYARAM, K.C., 2006. Catfishes of India. Delhi: Narendera Publishing House.

KAMARUDDIN, I.S., MUSTAFA-KAMAL, A.S., CHRISTIANUS, A., DAUD, S.K., AMIN, S.M.N. and YU-ABIT, L., 2011. Length-weight relationship and condition factor of three dominant species from the Lake TasikKenyir, Terengganu, Malaysia. Su Ürünleri Dergisi, vol. 6, no. 7, pp. 852.
KHALID, S., KHAN, W., DAS, S.N., AHMAD, A., MEHMOOD, S.A., PAHANWAR, W.A., AHMED, S., KAMAL, M., WAQAS, M., WAQAS, R.M., HASSAN, H.U., ZAHOOR, S. and MAQBOOL, A., 2021. Evaluation of ecto and endo parasitic fauna of Schizothorax plagiostomus inhabitants of river Swat, Khyber PakhtunKhwa, Pakistan. Brazilian Journal of Biology $=$ Revista Brasileira de Biologia, vol. 81, no. 1, pp. 98-104. http://dx.doi.org/10.1590/15196984.222215. PMid:32578670.

KHAN, W., NAQVI, S.M.H.M., AHMAD, N., KAMAL, M., HASSAN, H., NOOR, A., KHAN, S., AHMAD, J., ULLAH, U., AKHTAR, S. and SHADMAN, M., 2021. Prevalence of rhabdochoniasis in snow trout of river Swat and river Panjkora, Khyber Pakhtunkhwa province, Pakistan. Brazilian Journal of Biology $=$ Revista Brasileira de Biologia, vol. 82, pp. e238874. PMid:34037079.

MIRZA, M.R., 1990. Pakistan Ki Taza Pani Ki Machliyan. Lahore: Polymer Publications.

MIRZA, M.R. and SANDHU, I.A., 2007. Fishes of the Punjab. Lahore: Polymer Publications.

OFFEM, B.O., AKEGBEJO-SAMSONS, Y. and OMONIYI, I.T., 2007. Biological assessment of Oreochromisniloticus (Pisces: Cichlidae; Linne, 1958) in a tropical floodplain river. African Journal of Biotechnology, vol. 6, no. 16

PERVIN, M.R. and MORTUZA, M.G., 2008. Notes on length-weight relationship and condition factor of fresh water fish, Labeoboga (Hamilton) (Cypriniformes: cyprinidae). University Journal of Zoology. Rajshahi University, vol. 27, pp. 97-98. http://dx.doi. org/10.3329/ujzru.v27i0.1964.

TALWAR, P.K. and JHINGRAN, A.J.K., 1991. Inland fishes of India and adjacent countries. New Delhi: Oxford and IBH Publishing Co. Pvt. Ltd. 